\title{
EFEKTIVITAS DAN PENGARUH PNPM MANDIRI PERDESAAN, ALOKASI DANA DESA, PENDAPATAN ASLI DESA DAN JUMLAH PENDUDUK TERHADAP JUMLAH KEPALA KELUARGA MISKINDI KABUPATEN KEBUMEN TAHUN 2009-2011
}

\author{
Oleh: \\ Prihartini Budi Astuti \\ E-mail : eti_toro@yahoo.com
}

\section{RINGKASAN}

Permasalahan kemiskinan merupakan permasalahan yang kompleks dan multidimensional, oleh karena itu upaya pengentasan kemiskinan harus dilakukan secara komprehensif, mencakup berbagai aspek kehidupan masyarakat dan dilaksanakan secara terpadu. Masalah kemiskinan di Indonesia tidak dapat dipisahkan dari konteks kelembagaan dan tata kelola pemerintahan. Setelah kurang lebih enam tahun sejak pelaksanaan otonomi daerah, sejumlah tantangan tetap ada, namun proses desentralisasi memiliki potensi untuk lebih meningkatkan kesejahteraan dengan membawa pelayanan lebih dekat kepada masyarakat Indonesia, dan terutama kepada orang miskin. Upaya pengurangan kemiskinan sedang dalam proses menjadi lokal, dan pemerintah daerah kini mengikuti jejak nasional dalam menyiapkan strategi pengurangan kemiskinan.

Penelitian ini bertujuan untuk mengetahui efektivitas dan pengaruh PNPM Mandiri Perdesaan Simpan Pinjam Perempuan (SPP) , PNPM Mandiri Perdesaan Non-SPP, Alokasi Dana Desa (ADD), Pendapatan Asli Desa (PADs) dan jumlah penduduk terhadap jumlah keluarga miskin di Kabupaten Kebumen pada tahun 2009-2011 baik secara parsial maupun simultan.

Hasil analisis data menunjukkan bahwa variabel PNPM Mandiri Perdesaan Simpan Pinjam Perempuan (SPP) berpengaruh secara positif dan signifikan terhadap jumlah KK miskin dengan nilai koefisien sebesar 0,005459, PNPM Mandiri Perdesaan Non-SPP berpengaruh negatif tetapi tidak signifikan terhadap jumlah KK miskin dengan nilai koefisien sebesar -0,002676, Alokasi Dana Desa (ADD) berpengaruh negatif dan signifikan terhadap jumlah KK miskin dengan nilai koefisien sebesar -0,010433, Pendapatan Asli Desa (PADs) berpengaruh negatif dan signifikan terhadap jumlah KK miskin dengan nilai koefisien sebesar $-0,022590$ sedangkan variabel Jumlah Penduduk berpengaruh secara negatif tetapi tidak signifikan terhadap jumlah KK miskin dengan nilai koefisien sebesar $\quad-0,017860$. Dari hasil analisis tersebut, diperoleh kesimpulan bahwa PNPM Mandiri Perdesaan Simpan Pinjam Perempuan (SPP), PNPM Mandiri Perdesaan Non-SPP, Alokasi Dana Desa (ADD), dan Pendapatan Asli Desa (PADs) efektif dalam pengentasan kemiskinan di Kabupaten Kebumen tahun 2009 - 2011, karena secara umum telah terjadi keberhasilan program, keberhasilan sasaran dan pencapaian tujuan secara menyeluruh.

Kata kunci : jumlah KK miskin, PNPM Mandiri Perdesaan, Alokasi Dana Desa, Pendapatan Asli Desa dan jumlah penduduk 


\section{PENDAHULUAN}

$\begin{array}{ccc}\begin{array}{c}\text { Salah } \\ \text { pembangunan }\end{array} & \text { satu } & \text { tujuan } \\ \text { nasional } & \text { adalah }\end{array}$ meningkatkan kinerja perekonomian agar mampu menciptakan lapangan kerja dan menata kehidupan yang layak bagi seluruh rakyat yang pada gilirannya akan mewujudkan kesejahteraan bagi masyarakat Indonesia. Salah satu sasaran pembangunan nasional adalah menurunkan jumlah penduduk miskin, karena kemiskinan merupakan salah satu penyakit ekonomi yang harus diatasi. Permasalahan kemiskinan merupakan permasalahan yang kompleks dan multidimensional, oleh karena itu upaya pengentasan kemiskinan harus dilakukan secara komprehensif, mencakup berbagai aspek kehidupan masyarakat dan dilaksanakan secara terpadu.

Republik Indonesia telah membuat langkah yang mengesankan dalam mengurangi kemiskinan selama beberapa dekade terakhir, meskipun pernah terjadi kemunduran sebagai akibat dari krisis keuangan Asia pada tahun 1997/1998. Income Poverty Headcounts yang diukur dengan garis kemiskinan nasional telah menurun terus sejak tahun 1999. Pada tahun 2004, tingkat kemiskinan sekali lagi berada di bawah tingkat kemiskinan sebelum krisis, yaitu kurang dari 17\% dari populasi. Akan tetapi, tantangan besar tetap ada dalam meningkatkan kesejahteraan di negara terpadat ke-4 di dunia, di mana tingkat kemiskinan $17 \%$ diterjemahkan menjadi lebih dari 36 juta orang miskin. Dan jumlah itu adalah jumlah kemiskinan absolut, yang tidak mempertimbangkan faktor kesejahteraan yang lebih luas seperti halnya akses ke permodalan atau pelayanan (services) (World Bank, 2012)

Masalah kemiskinan di indonesia tidak dapat dipisahkan dar pemerintahan. Setelah kurang lebih enam tahun sejak pelaksanaan otonomi daerah, sejumlah tantangan tetap ada, namun proses desentralisasi memiliki potensi untuk lebih meningkatkan kesejahteraan dengan membawa pelayanan lebih dekat kepada masyarakat Indonesia, dan terutama kepada orang miskin. Upaya pengurangan kemiskinan sedang dalam proses menjadi lokal, dan pemerintah daerah kini mengikuti jejak nasional dalam menyiapkan strategi pengurangan kemiskinan.

Banyak faktor multidimensi yang saling berinteraksi untuk menyebabkan kemiskinan di Indonesia. Menurut hasil penelitian Country Poverty Analysis (CPA) for Indonesia yang dilakukan oleh Asian Development Bank pada tahun 2006, penyebab kemiskinan di Indonesia adalah (i) kurangnya akses terhadap kualitas, makanan terjangkau, (ii) kurangnya akses ke pelayanan kesehatan yang bermutu; (iii) kurangnya akses ke pelayanan pendidikan yang berkualitas; (iv) kurangnya akses terhadap peluang kerja dan usaha; (v) kurangnya akses ke perumahan dan sanitasi; (vi) kurangnya akses ke air bersih; (vii) kurangnya hak atas tanah; (viii) memburuknya kualitas lingkungan dan kurangnya akses terhadap sumber daya alam; (ix) konflik kekerasan; dan (x) kurangnya partisipasi. Penyebab ini dapat diartikan sebagai kurangnya akses ke berbagai bentuk modal manusia, modal fisik, finansial, alam 
dan sosial (Asian Development Bank, 2006)

Meskipun masyarakat miskin telah mendapatkan bantuan program pengentasan kemiskinan, tapi hasilnya tidak seperti yang diharapkan. Masyarakat miskin yang telah tersentuh program pengentasan kemiskinan, tetap saja tidak beranjak dari kondisi kemiskinannya. Karena itu, pasti ada yang salah dalam pelaksanaan program pengentasan kemiskinan tersebut. Menurut $\mathrm{Abu}$ Huraerah (2006), kekeliruan paradigmatik penanggulangan kemiskinan yang selama ini terjadi antara lain: Pertama, masih berorientasi pada aspek ekonomi daripada aspek multidimensional. Penanggulangan kemiskinan dengan fokus perhatian pada aspek ekonomi terbukti mengalami kegagalan, karena pengentasan kemiskinan yang direduksi dalam soal-soal ekonomi tidak akan mewakili persoalan kemiskinan yang sebenarnya. Dalam konteks budaya, orang miskin diindikasikan dengan terlembaganya nilai-nilai seperti apatis, apolitis, fatalistik, ketidakberdayaan dan sebagainya. Sementara dalam konteks dimensi struktural atau politik, orang yang mengalami kemiskinan ekonomi pada hakekatnya karena mengalami kemiskinan struktural dan politis. Kedua, program penanggulangan kemiskinan lebih bernuansa karitatif (kemurahan hati) daripada produktivitas. Penanggulangan kemiskinan yang hanya didasarkan atas pertimbangan karitatif, tidak akan muncul dorongan dari masyarakat miskin sendiri untuk berupaya bagaimana mengatasi kemiskinannya. Mereka akan selalu menggantungkan diri pada bantuan yang diberikan pihak lain. Padahal program penanggulangan kemiskinan seharusnya diarahkan supaya mereka menjadi produktif. Ketiga, memosisikan masyarakat miskin sebagai objek daripada subjek. Seharusnya, mereka dijadikan sebagai subjek, yaitu sebagai pelaku perubahan yang aktif terlibat dalam aktivitas program penanggulangan kemiskinan. Keempat, pemerintah masih sebagai penguasa daripada fasilitator. Dalam penanganan kemiskinan, pemerintah masih bertindak sebagai penguasa yang kerapkali turut campur tangan terlalu luas dalam kehidupan orang-orang miskin. Sebaliknya, pemerintah semestinya bertindak sebagai fasilitator, yang tugasnya mengembangkan potensi-potensi yang mereka miliki (Pikiran Rakyat, 02 Januari 2006).

Untuk memperbaiki kekeliruan paradigmatik penanggulangan kemiskinan seperti yang telah tersebut diatas dan untuk meningkatkan efektivitas penanggulangan kemiskinan serta penciptaan lapangan kerja, pemerintah meluncurkan Program Nasional Pemberdayaan Masyarakat (PNPM) Mandiri mulai tahun 2007. Melalui PNPM Mandiri dirumuskan kembali mekanisme upaya penanggulangan kemiskinan yang melibatkan unsur masyarakat mulai dari tahap perencanaan, pelaksanaan hingga pemantauan dan evaluasi. Melalui proses pembangunan partisipatif, kesadaran kritis dan kemandirian masyarakat, terutama masyarakat miskin, dapat ditumbuhkembangkan sehingga mereka bukan lagi sebagai obyek, melainkan sebagai subyek upaya penanggulangan kemiskinan.

Pelaksanaan PNPM Mandiri tahun 2007 dimulai dengan Program 
Pengembangan Kecamatan (PPK) sebagai dasar pengembangan pemberdayaan masyarakat di perdesaan beserta program pendukungnya seperti PNPM Generasi, Program Penanggulangan Kemiskinan di Perkotaan (P2KP) sebagai dasar bagi pengembangan pemberdayaan masyarakat di perkotaan dan Percepatan Pembangunan Desa Tertinggal dan Khusus (P2DTK) untuk pengembangan desa tertinggal, pasca bencana dan konflik. Mulai tahun 2008, PNPM Mandiri diperluas dengan melibatkan Program Pengembangan Infrastruktur Sosial Ekonomi Wilayah (PISEW) untuk mengintegrasikan pusat-pusat pertumbuhan ekonomi dengan daerah sekitarnya. PNPM Mandiri diperkuat dengan berbagai program pemberdayaan masyarakat yang dilaksanakan oleh berbagai departemen/sektor dan pemerintah daerah (PNPM Mandiri, 2010)

Kabupaten Kebumen adalah salah satu kabupaten di Provinsi Jawa Tengah bagian selatan yang memiliki luas wilayah $4.118,5 \mathrm{~km}^{2}$, dengan jumlah penduduk 1.337.884 jiwa dan tingkat pertumbuhan penduduk $0,78 \%$. PDRB per kapita sebesar Rp. 2.096.037, dengan jumlah penduduk miskin berdasarkan data profil daerah tahun 2009 mencapai 371.664 jiwa (27,78\%), dan sebagaimana Keputusan Bupati No. 050/69/KEP/2007 tanggal 1 Pebruari 2007 tentang Desa Tertinggal di Kabupaten Kebumen Tahun 2007, sebanyak 329 desa adalah desa tertinggal, dimana 103 desa diantaranya merupakan desa sangat tertinggal (Pemerintah Kabupaten Kebumen, 2011)

Dalam kegiatan "Konsultasi

Publik Pembahasan Raperda Kemiskinan Kabupaten Kebumen
Tahun 2011" yang diadakan pada tanggal 10 Februari 2011, diungkapkan data bahwa Kabupaten Kebumen menduduki peringkat ketiga kabupaten termiskin di Jawa Tengah (25,73\%), setelah Kabupaten Wonosobo $(25,91 \%)$ dan Kabupaten Rembang $(25,86 \%)$. Hal ini berarti bahwa masalah kemiskinan di Kabupaten Kebumen merupakan masalah besar yang harus segera diatasi

Oleh karena itu, peneliti tertarik untuk melakukan penelitian tentang efektivitas dan pengaruh PNPM Mandiri Perdesaan, Alokasi Dana Desa (ADD) dan Pendapatan Asli Desa (PADs) terhadap penurunan jumlah kepala keluarga miskin di Kabupaten Kebumen pada tahun 2009/2010.

Berdasarkan latar belakang tersebut diatas, maka pertanyaan penelitian dalam penelitian ini adalah bagaimana efektivitas dan pengaruh PNPM Mandiri Perdesaan Simpan Pinjam Perempuan (SPP), PNPM Mandiri Perdesaan Non-Simpan Pinjam Perempuan (NonSPP), Alokasi Dana Desa (ADD), Pendapatan Asli Desa (PADs) dan jumlah penduduk terhadap jumlah kepala keluarga miskin di Kabupaten Kebumen pada tahun 2009-2011.

Tujuan dari penelitian ini adalah:

1. Untuk mengetahui pengaruh PNPM Mandiri Perdesaan Simpan Pinjam Perempuan (SPP), PNPM Mandiri Perdesaan Non-SPP, Alokasi Dana Desa (ADD), Pendapatan Asli Desa (PADs) dan jumlah penduduk terhadap jumlah kepala keluarga miskin di Kabupaten Kebumen pada tahun 2009-2011 baik secara parsial maupun simultan.

2. Untuk mengetahui efektivitas PNPM Mandiri Perdesaan Simpan Pinjam Perempuan (SPP), PNPM 
Mandiri Perdesaan Non-SPP, Alokasi Dana Desa (ADD), Pendapatan Asli Desa (PADs) dan jumlah penduduk terhadap jumlah kepala keluarga miskin di Kabupaten Kebumen pada tahun 2009-2011.

\section{METODE ANALISIS}

\section{Populasi dan Teknik Pengambilan Sampel}

Penelitian ini merupakan penelitian kuantitatif deskriptif. Subyek dalam penelitian ini adalah desa yang menerima dana PNPM Mandiri Perdesaan-Simpan Pinjam Perempuan, PNPM Mandiri Perdesaan - NonSPP, Alokasi Dana Desa (ADD) dan Pendapatan Asli Desa (PADs) di Kabupaten Kebumen pada tahun 20092011, sedangkan obyek dalam penelitian ini adalah efektivitas dan pengaruh PNPM Mandiri Perdesaan, ADD, PADs dan jumlah penduduk terhadap jumlah kepala keluarga miskin di Kabupaten Kebumen tahun 2009-2011.

Jenis data yang dipakai dalam penelitian ini adalah data sekunder, yaitu data yang diperoleh dari instansi terkait yang menangani masalah kemiskinan di Kabupaten Kebumen, serta data-data dari literatur lain yang ada kaitannya dengan penelitian ini. Data sekunder yang diperlukan dalam penelitian ini yaitu jumlah kepala keluarga miskin, alokasi dana PNPM Mandiri Perdesaan, ADD dan PADs yang diterima oleh masing-masing desa di Kabupaten Kebumen, jumlah penduduk per desa pada tahun 20092011, serta data penunjang lain yang mendukung penelitian ini.

Populasi dalam penelitian ini adalah seluruh desa di Kabupaten
Kebumen yang berjumlah 449 desa. Sedangkan sampelnya adalah desa yang menerima dana PNPM Mandiri Perdesaan - Simpan Pinjam Perempuan (SPP), PNPM Mandiri Perdesaan - NonSPP, Alokasi Dana Desa dan Pendapatan Asli Desa di Kabupaten Kebumen tahun 2009 2011 yang berjumlah 226 desa.

\section{Definisi Operasional Variabel}

Variabel yang akan diteliti dalam penelitian ini adalah jumlah kepala keluarga miskin, jumlah alokasi dana PNPM Mandiri Perdesaan Simpan Pinjam Perempuan (SPP), PNPM Mandiri Perdesaan Non-SPP, Alokasi Dana Desa (ADD), Pendapatan Asli Desa (PADs) serta jumlah penduduk. Sedangkan definisi operasionalnya adalah sebagai berikut:

1. Jumlah kepala keluarga miskin Jumlah kepala keluarga miskin dilihat dari perkembangan jumlah kepala keluarga miskin per desa di Kabupaten Kebumen tahun 20092011

2. PNPM Mandiri Perdesaan - Simpan Pinjam Perempuan (SPP)

PNPM Mandiri Perdesaan - Simpan Pinjam Perempuan (SPP) adalah jumlah alokasi dana PNPM Mandiri Perdesaan yang dialokasikan untuk program Simpan Pinjam Perempuan (SPP) di masing-masing desa

3. PNPM Mandiri Perdesaan NonSPP

PNPM Mandiri Perdesaan NonSPP adalah jumlah alokasi dana PNPM Mandiri Perdesaan yang dialokasikan untuk programprogram selain program Simpan Pinjam Perempuan (SPP) di masing-masing desa

4. Alokasi Dana Desa (ADD)

Alokasi Dana Desa adalah dana yang dialokasikan oleh Pemerintah 
Kabupaten/Kota untuk desa, yang bersumber dari bagian dana perimbangan keuangan pusat dan daerah yang diterima oleh Kabupaten/Kota

5. Pendapatan Asli Desa (PADs)

Pendapatan Asli Desa adalah pendapatan desa terdiri dari tanah kas desa, pasar / kios desa, pasar hewan desa, tambatan perahu, bangunan desa, obyek rekreasi yang diurus desa, pelelangan ikan yang dikelola oleh desa dan lain-lain kekayaan milik desa

6. Jumlah penduduk

Jumlah penduduk dalam penelitian ini adalah jumlah penduduk per desa yang menjadi subyek penelitian.

\section{Teknik Analisis Data}

Penelitian ini menggunakan metode analisis regresi berganda. Analisis regresi berganda dilakukan untuk mengetahui pengaruh dan efektivitas PNPM Mandiri PerdesaanSPP, PNPM Mandiri PerdesaanNonSPP, ADD, PADs dan jumlah penduduk terhadap jumlah $\mathrm{KK}$ miskin di Kabupaten Kebumen tahun 20092011. Analisis regresi berganda dalam penelitian ini akan dilakukan dengan program E-Views versi 5.0. Program ini digunakan untuk mengestimasi bagaimana dan seberapa besar pengaruh PNPM Mandiri Perdesaan, ADD PADs dan jumlah penduduk sebagai variabel independen terhadap pengentasan kemiskinan di Kabupaten Kebumen tahun 2009-2011 sebagai variabel dependen. Pemakaian program E-Views disebabkan karena data yang akan diolah dalam penelitian ini adalah data panel. Data panel yaitu data gabungan antara data cross-section dan data time-series (Suliyanto, 2011 : 229).
Metode estimasi model regresi dengan menggunakan data panel dapat dilakukan melalui tiga pendekatan, antara lain:

1). Metode Pooled Least Square Model

Pooled Least Square Model merupakan metode estimasi model regresi data panel yang paling sederhana dengan asumsi intercept dan koefisien slope yang konstan antar waktu dan cross-section (Common Effect). Pada dasarnya, Pooled Least Square Model merupakan metode yang meminimumkan jumlah error kuadrat sama seperti OLS, tetapi data yang digunakan bukan data time-series saja atau cross section saja melainkan data panel yang diterapkan dalam bentuk pooled. Persamaan pada estimasi menggunakan Pooled Least Square Model dapat dituliskan dalam bentuk sebagai berikut:

$$
\begin{aligned}
& Y_{i t}=\alpha+x^{j}{ }_{i t} \beta_{j}+\varepsilon_{i t} \\
& i=1,2, \ldots, N \text { dan } t=1,2, \ldots, T
\end{aligned}
$$

2). Metode Fixed Effect Model

Fixed Effect Model merupakan metode estimasi model regresi data panel dengan asumsi koefisien slope kontan dan intercept berbeda antar unit cross-section tetapi intercept konstan antar waktu (Fixed Effect). Fixed Effect Model mengatasi permasalahan asumsi Pooled Least Square Model yang sulit dipenuhi. Generalisasi secara umum sering dilakukan adalah dengan memasukan variabel dummy untuk menghasilkan nilai koefisien slope atau parameter yang berbeda antar unit cross section (Baltagi, 2005). Pendekatan dengan memasukkan variabel dummy ini dikenal dengan 
sebutan Fixed Effect Model atau Least Square Dummy Variable (LSDV) atau disebut juga Covariance Model. Persamaan pada estimasi menggunakan Fixed Effect Model dapat dituliskan dalam bentuk sebagai berikut:

$$
\mathbf{Y}_{\mathrm{it}}=\boldsymbol{\alpha}_{\mathrm{i}}+\boldsymbol{\beta} \mathbf{j} \mathbf{x}_{\mathrm{it}}^{\mathbf{j}_{\mathrm{i}}}+\sum_{i=2}^{n} \quad \boldsymbol{\alpha i} \mathbf{D}_{\mathrm{i}}+\mathbf{e}_{\mathrm{it}}
$$

\section{3). Metode Random Effect Model}

Random Effect Model merupakan metode estimasi model regresi data panel dengan asumsi koefisien slope konstan dan intercept berbeda antar individu dan antar waktu (Random Effect). Keputusan untuk memasukan variabel dummy dalam Fixed Effect Model memiliki konsekuensi berkurangnya degree of freedom yang akhirnya dapat mengurangi efisiensi dari parameter yang diestimasi. Oleh karena itu, dalam model data panel dikenal pendekatan yang ketiga yaitu Random Effect Model (Baltagi, 2005). Random Effect Model disebut juga model komponen error (error component model) karena di dalam model ini parameter yang berbeda antar unit cross section maupun antar waktu dimasukkan ke dalam error. Persamaan pada estimasi menggunakan Random Effect Model dapat dituliskan dalam bentuk sebagai berikut:

$Y_{i t}=\alpha_{1}+\beta_{j} x^{j}{ }_{i t}+\varepsilon_{i t}$ dengan $\varepsilon_{i t}=$ $\mathbf{u}_{\mathrm{i}}+\mathbf{v}_{\mathrm{t}}+\mathbf{w}_{\mathrm{it}}$

Untuk memilih model mana yang paling tepat digunakan untuk pengolahan data panel, maka terdapat beberapa pengujian yang dapat dilakukan, antara lain:

1). Chow Test adalah pengujian untuk memilih apakah model yang digunakan Pooled Least Square Model atau Fixed Effect Model. Dalam pengujian ini dilakukan dengan hipotesis sebagai berikut:

$\mathrm{H}_{0}$ : Pooled Least Square Model

$\mathrm{H}_{1}$ : Fixed Effect Model

Dasar penolakan terhadap hipotesis nol tersebut adalah dengan menggunakan $\mathrm{F}$ Statistic seperti yang dirumuskan oleh Chow:

Chow $=\frac{(\text { RRSS-URSS/N-1) }}{\mathrm{F}}$

$\alpha(\mathrm{N}-1, \mathrm{NT}-\mathrm{N}-\mathrm{K})$

$$
\text { URSS/(NT - N - K) }
$$

dimana:

RRSS = Restricted Residual Sum Square (Sum Square Residual PLS)

URSS = Unrestricted Residual Sum Square (Sum Square Residual Fixed)

$\mathrm{N}=$ Jumlah data cross-section

$\mathrm{T}=$ Jumlah data time series

$\mathrm{K}=$ Jumlah variabel independen

Dimana pengujian ini mengikuti distribusi $\mathrm{F}$ yaitu $\mathrm{F} K(\mathrm{~N}-1, \mathrm{NT}-$ $\mathrm{N}-\mathrm{K}$ ). Jika nilai Chow Statistics (F Statistic) hasil pengujian lebih besar dari $\mathrm{F}$ Tabel, maka cukup bukti bagi kita untuk melakukan penolakan terhadap $\mathrm{H}_{0}$ sehingga model yang kita gunakan adalah Fixed Effect Model, begitu juga sebaliknya.

2). Hausman Test adalah pengujian statistik sebagai dasar pertimbangan kita dalam memilih apakah menggunakan Fixed Effect Model atau Random Effect Model. Pengujian ini dilakukan dengan hipotesis sebagai berikut: $\mathrm{H}_{0}$ : Random Effects Model $\mathrm{H}_{1}$ : Fixed Effects Model 
Sebagai dasar penolakan $\mathrm{H}_{0}$ maka digunakan statistik Hausman dan membandingkannya dengan $\mathrm{Chi}$ square. Statistik Hausman dirumuskan dengan:

\section{$\mathrm{H}=\left(\boldsymbol{\beta}_{\mathrm{REM}}-\boldsymbol{\beta}_{\mathrm{fEM}}\right)^{\prime} \quad\left(\mathrm{M}_{\mathrm{FEM}}-\right.$ M $\left._{\text {REM }}\right)^{-1}\left(\beta_{\text {REM }}-\beta_{\text {fEM }}\right) \sim \chi^{2}$} (k)

dimana $M$ adalah matriks kovarians untuk parameter $\beta$ dan $\mathrm{k}$ adalah derajat bebas yang merupakan jumlah variabel independen. Jika nilai $\mathrm{H}$ hasil pengujian lebih besar dari $\chi^{2}(\mathrm{k})$, maka cukup bukti untuk melakukan penolakan terhadap $\mathrm{H}_{0}$ sehingga model yang digunakan adalah Fixed Effect Model, begitu juga sebaliknya.

Sedangkan untuk mengukur efektivitas, terdapat cara pengukuran terhadap efektivitas yang secara umum dan yang paling menonjol adalah sebagai berikut:

a. Keberhasilan program

b. Keberhasilan sasaran

c. Kepuasan terhadap program

d. Tingkat input dan output

e. Pencapaian tujuan menyeluruh
Untuk menganalisis pengaruh dan efektivitas PNPM Mandiri Perdesaan - Simpan Pinjam Perempuan (SPP), PNPM Mandiri Perdesaan - NonSPP, Alokasi Dana Desa (ADD), Pendapatan Asli Desa (PADs) dan jumlah penduduk terhadap penurunan jumlah keluarga miskin di Kabupaten Kebumen pada tahun 2009-2011 akan digunakan metode analisis regresi berganda. Karena data yang akan dianalisis adalah data panel (data gabungan antara data cross-section dan data time series), maka analisis data akan dilakukan dengan bantuan program E-Views versi 6.

Untuk menganalisis pengaruh PNPM Mandiri Perdesaan, ADD, PAD dan jumlah penduduk terhadap jumlah KK miskin di Kabupaten Kebumen tahun 2009-2011, digunakan rumus persamaan regresi berganda sebagai berikut:

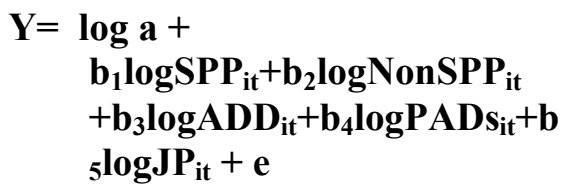

\section{HASIL ANALISIS}

\section{A. Hasil Penelitian}

Tabel 1. Hasil Analisis Data Dengan Fixed Effect Model

\begin{tabular}{crrrr}
\hline Variabel & \multicolumn{1}{c}{ Koefisien } & Std.Error & \multicolumn{1}{c}{ t-Statistik } & \multicolumn{1}{c}{ Prob. } \\
\hline C & 3.138150 & 0.098977 & 31.70573 & 0.0000 \\
SPP & 0.005459 & 0.002662 & 2.050956 & 0.0409 \\
NONSPP & -0.002676 & 0.002165 & -1.235865 & 0.2172 \\
ADD & -0.010433 & 0.003276 & -3.184685 & 0.0016 \\
PADS & -0.022590 & 0.009384 & -2.407397 & 0.0165 \\
JP & -0.017860 & 0.017462 & -1.022792 & 0.3070 \\
F-statistic & 2347.040 & & & \\
Prob (F-statistic) & 0.000000 & & & \\
Adjusted $R$ Square & 0.998747 & & & \\
D.W. statistik & 2.561535 & & & \\
Sumber : Data primer diolah, 2013 & & & &
\end{tabular}


1. Kostanta $=3,138150$

Konstanta 3,138150 berarti apabila variabel PNPM Mandiri Perdesaan-SPP, PNPM Mandiri Perdesaan Non-SPP, ADD, PADs dan jumlah penduduk tetap atau konstan, maka akan terjadi peningkatan jumlah $\mathrm{KK}$ miskin sebesar 3,1381 persen.

2. Koefisen regresi PNPM Mandiri Perdesaan-SPP = 0,005459

Koefisien regresi variabel PNPM Mandiri Perdesaan Simpan Pinjam Perempuan (SPP) sebesar 0,005459, artinya bahwa ketika terjadi penambahan dana PNPM Mandiri Perdesaan Simpan Pinjam Perempuan (SPP) sebesar 1 persen, maka akan terjadi peningkatan jumlah KK miskin sebesar 0,0054 persen.

3. Koefisen regresi variabel PNPM Mandiri Non- Simpan Pinjam Perempuan (NonSPP) $=$ $-0,002676$

Koefisien regresi variabel PNPM Mandiri Perdesaan NonSimpan Pinjam Perempuan (NonSPP) sebesar -0,002676, artinya bahwa ketika terjadi penambahan dana PNPM Mandiri Perdesaan Non-Simpan Pinjam Perempuan (NonSPP) sebesar 1 persen, maka akan terjadi penurunan jumlah KK miskin sebesar 0,0026 persen.

4. Koefisen regresi variabel Alokasi Dana Desa = -0,010433 Koefisien regresi variabel Alokasi Dana Desa sebesar 0,010433, artinya bahwa ketika terjadi penambahan dana Alokasi Dana Desa (ADD) sebesar 1 persen, maka akan terjadi penurunan jumlah KK miskin sebesar 0,0104 persen.

5. Koefisen regresi variabel Pendapatan Asli Desa = 0,022590

Koefisien regresi variabel Pendapatan Asli Desa sebesar 0,022590 , artinya bahwa ketika terjadi penambahan dana Pendapatan Asli Desa (PADs) sebesar 1 persen, maka akan terjadi penurunan jumlah $\mathrm{KK}$ miskin sebesar 0,0225 persen.

6. Koefisen regresi variabel Jumlah Penduduk $=-0,017860$

Koefisien regresi variabel Jumlah Penduduk sebesar 0,017860 , artinya bahwa ketika terjadi penambahan jumlah penduduk sebesar 1 persen, maka akan terjadi penurunan jumlah KK miskin sebesar 0,0178 persen.

Uji selanjutnya adalah uji parsial (uji t). Pengujian parsial ini digunakan untuk mengetahui tingkat signifikansi tiap variabel independen. Hasil uji parsial (uji t) dalam Fixed Effect Model dapat dilihat pada Tabel:1. Dari tabel tersebut, dapat dijelaskan sebagai berikut:

1. Variabel PNPM Mandiri Perdesaan - Simpan Pinjam Perempuan (SPP)

Berdasarkan tabel, terlihat bahwa tingkat probabilitasnya adalah 0,0409 yang berarti lebih kecil dari 0,05 sehingga dapat dikatakan bahwa variabel PNPM Mandiri PerdesaanSimpan Pinjam Perempuan (SPP) berpengaruh secara 
positif dan signifikan terhadap jumlah KK miskin di Kabupaten Kebumen pada tahun 2009-2011

2. Variabel PNPM Mandiri Perdesaan Non-Simpan Pinjam Perempuan (NonSPP)

Berdasarkan Tabel:1, ditunjukkan bahwa tingkat probabilitasnya adalah 0,2172 yang berarti lebih besar dari 0,05 sehingga dapat dikatakan bahwa variabel PNPM Mandiri Perdesaan Non-Simpan Pinjam Perempuan

(NonSPP) berpengaruh secara negatif tetapi tidak signifikan terhadap jumlah KK miskin di Kabupaten Kebumen pada tahun 2009-2011

3. Variabel Alokasi Dana Desa (ADD)

Berdasarkan Tabel:1, ditunjukkan bahwa tingkat probabilitasnya adalah 0,0016 yang berarti lebih kecil dari 0,05 sehingga dapat dikatakan bahwa variabel Alokasi Dana Desa berpengaruh secara negatif dan signifikan terhadap jumlah KK miskin di Kabupaten Kebumen pada tahun 2009-2011

4. Variabel Pendapatan Asli Desa (PADs)

Berdasarkan Tabel:1, ditunjukkan bahwa tingkat probabilitasnya adalah 0,0165 yang berarti lebih kecil dari 0,05 , sehingga dapat dikatakan bahwa variabel Pendapatan Asli Desa (PADs) berpengaruh secara negatif dan signifikan terhadap jumlah KK miskin di
Kabupaten Kebumen pada tahun 2009-2011.

5. Variabel Jumlah Penduduk (JP) Berdasarkan Tabel:1 diatas, ditunjukkan bahwa tingkat probabilitasnya adalah 0,3070 yang berarti lebih besar dari 0,05 , sehingga dapat dikatakan bahwa variabel Jumlah Penduduk berpengaruh secara negatif tetapi tidak signifikan terhadap jumlah KK miskin di Kabupaten Kebumen pada tahun 2009-2011

Hasil uji $\mathrm{F}$ dalam Fixed Effect Model dapat dilihat dalam Tabel 4.13. Berdasarkan tabel tersebut, ditunjukkan bahwa nilai $F_{\text {hitung }}$ adalah sebesar 2347.040 dengan tingkat signifikansi 0,000 sehingga dapat disimpulkan bahwa variabel PNPM Mandiri Perdesaan-Simpan Pinjam Perempuan (SPP), PNPM Mandiri Perdesaan Non-Simpan Pinjam Perempuan (NonSPP), Alokasi Dana Desa (ADD), Pendapatan Asli Desa (PADs) dan Jumlah Penduduk (JP) secara bersama-sama berpengaruh secara signifikan terhadap jumlah $\mathrm{KK}$ miskin di Kabupaten Kebumen pada tahun 2009-2011. Dari Tabel 4.1 juga terlihat bahwa nilai koefisien determinasi (adjusted $\mathrm{R}^{2}$ ) adalah sebesar 0.998747 yang berarti bahwa 99,87 persen jumlah KK miskin di Kabupaten Kebumen pada tahun 2009-2011 dipengaruhi oleh variabel PNPM Mandiri Perdesaan Simpan Pinjam Perempuan (SPP), PNPM Mandiri Perdesaan Non-Simpan Pinjam Perempuan (NonSPP), Alokasi Dana Desa (ADD), Pendapatan Asli Desa (PADs) dan Jumlah Penduduk (JP), sedangkan sisanya 
(0,13 persen) dipengaruhi oleh variabel lain yang tidak ada dalam penelitian ini.

\section{KESIMPULAN}

1. Tujuan pertama dari penelitian ini adalah untuk mengetahui pengaruh PNPM Mandiri Perdesaan Simpan Pinjam Perempuan (SPP), PNPM Mandiri Perdesaan Non-SPP, Alokasi Dana Desa (ADD), Pendapatan Asli Desa (PADs) dan jumlah penduduk terhadap jumlah kepala keluarga miskin di Kabupaten Kebumen pada tahun 2009-2011 baik secara parsial maupun simultan. Dari hasil analisis data, diperoleh kesimpulan sebagai berikut:

a. Variabel PNPM Mandiri Perdesaan-Simpan Pinjam Perempuan berpengaruh positif dan signifikan terhadap jumlah KK miskin di Kabupaten Kebumen dengan nilai koefisien 0,005459 , yang artinya ketika dana PNPM Mandiri Perdesaan-Simpan Pinjam Perempuan ditambah sebesar 1 persen, maka jumlah KK miskin akan bertambah sebesar 0,0054 persen.

b. Variabel PNPM Mandiri Perdesaan-Non Simpan Pinjam Perempuan berpengaruh negatif tetapi tidak signifikan terhadap jumlah KK miskin di Kabupaten Kebumen dengan nilai koefisien -0,002676 yang artinya ketika dana PNPM Mandiri Perdesaan-Non Simpan Pinjam Perempuan ditambah sebesar 1 persen, maka jumlah KK miskin akan berkurang sebesar 0,0026 persen.. c. Variabel Alokasi Dana Desa berpengaruh negatif dan signifikan terhadap jumlah KK miskin di Kabupaten Kebumen dengan nilai koefisien 0,010433 yang artinya ketika dana Alokasi Dana Desa ditambah sebesar 1 persen, maka jumlah KK miskin akan berkurang sebesar 0,010433 persen.

d. Variabel Pendapatan Asli Desa (PADs) berpengaruh secara negatif dan signifikan terhadap jumlah KK miskin di Kabupaten Kebumen dengan nilai koefisien $-0,022590$ yang artinya ketika dana PADs bertambah sebesar 1 persen, maka jumlah KK miskin akan berkurang sebesar 0,0225 persen.

e. Variabel Jumlah Penduduk berpengaruh secara negatif tetapi tidak terhadap jumlah KK miskin di Kabupaten Kebumen dengan nilai koefisien 0,017860 yang artinya, ketika jumlah penduduk bertambah sebesar 1 persen, maka jumlah KK miskin akan berkurang sebesar 0,0178 persen.

f. Nilai F hitung sebesar 2347,040 dengan angka probabilitas (Fprob.) 0,0000 dapat diambil kesimpulan bahwa variabel PNPM Mandiri Perdesaan Simpan Pinjam Perempuan (SPP), PNPM Mandiri Perdesaan Non-SPP, Alokasi Dana Desa (ADD), Pendapatan Asli Desa (PADs) dan jumlah penduduk secara bersama-sama mempunyai pengaruh yang siginifikan terhadap jumlah KK 
miskin di Kabupaten Kebumen

tahun 2009-2011.

2. Tujuan kedua dari penelitian ini adalah untuk mengetahui efektivitas PNPM Mandiri Perdesaan Simpan Pinjam Perempuan (SPP), PNPM Mandiri Perdesaan Non-SPP, Alokasi Dana Desa (ADD), Pendapatan Asli Desa (PADs) dan jumlah penduduk terhadap jumlah kepala keluarga miskin di Kabupaten Kebumen pada tahun 2009-2011. Untuk melihat efektivitas dalam penelitian ini adalah dengan menggunakan indikator keberhasilan program, keberhasilan sasaran, kepuasan terhadap program, tingkat input dan output serta pencapaian tujuan secara menyeluruh.

a. Dari hasil analisis data, diperoleh hasil bahwa variabel PNPM Mandiri Perdesaan Simpan Pinjam Perempuan (SPP), berpengaruh secara positif dan signifikan terhadap jumlah $\mathrm{KK}$ miskin di Kabupaten Kebumen tahun 2009-2011, yang berarti bahwa penambahan dana PNPM Mandiri Perdesaan Simpan Pinjam Perempuan (SPP) justru akan menambah jumlah KK miskin di Kabupaten Kebumen. Dari hasil tersebut, berarti tidak terjadi keberhasilan program, keberhasilan sasaran, serta pencapaian tujuan secara menyeluruh, karena tujuan utama dari penambahan dana PNPM Mandiri Perdesaan Simpan Pinjam Perempuan (SPP) adalah untuk mengurangi jumlah KK miskin, tetapi yang terjadi justru sebaliknya. Maka dari itu, dapat diambil kesimpulan bahwa PNPM Mandiri Perdesaan
Simpan Pinjam Perempuan (SPP) tidak efektif untuk mengurangi jumlah KK miskin di Kabupaten Kebumen tahun 2009-2011.

b. Dari hasil analisis data, diperoleh hasil bahwa variabel PNPM Mandiri Perdesaan Non-Simpan Pinjam Perempuan (NonSPP), berpengaruh secara negatif tetapi tidak signifikan terhadap jumlah KK miskin di Kabupaten Kebumen tahun 2009-2011, yang berarti bahwa dengan penambahan dana PNPM Mandiri Perdesaan Non-Simpan Pinjam Perempuan (NonSPP) maka jumlah KK miskin akan berkurang, tetapi dalam jumlah yang tidak signifikan. Dari hasil tersebut, berarti belum terjadi keberhasilan program, keberhasilan sasaran, serta pencapaian tujuan secara menyeluruh, karena meskipun penambahan dana PNPM Mandiri Perdesaan Non-Simpan Pinjam Perempuan (NonSPP) telah berhasil mengurangi jumlah KK miskin, tetapi jumlahnya tidak signifikan. Maka dari itu, dapat diambil kesimpulan bahwa PNPM Mandiri Perdesaan NonSimpan Pinjam Perempuan (Non-SPP) belum efektif untuk mengurangi jumlah KK miskin di Kabupaten Kebumen tahun 2009-2011.

c. Dari hasil analisis data, diperoleh hasil bahwa variabel Alokasi Dana Desa (ADD) berpengaruh negatif dan signifikan terhadap jumlah KK miskin di Kabupaten Kebumen tahun 2009-2011, yang berarti bahwa dengan penambahan dana Alokasi Dana Desa (ADD) maka jumlah KK 
miskin akan berkurang dalam jumlah yang signifikan. Hal ini berarti telah terjadi keberhasilan program, keberhasilan sasaran, serta pencapaian tujuan secara menyeluruh karena penambahan dana ADD secara signifikan telah berhasil mengurangi jumlah KK miskin di Kabupaten Kebumen tahun 2009-2011. Oleh karena itu, dapat diambil kesimpulan bahwa Alokasi Dana Desa (ADD) efektif dalam mengurangi jumlah KK miskin di Kabupaten Kebumen tahun 2009-2011.

d. Dari hasil analisis data, diperoleh hasil bahwa variabel Pendapatan Asli Desa (PADs) berpengaruh negatif dan signifikan terhadap jumlah KK miskin di Kabupaten Kebumen tahun 2009-2011, yang berarti bahwa dengan penambahan dana Pendapatan Asli Desa (PADs) maka jumlah KK miskin akan berkurang dalam jumlah yang signifikan. Hal ini berarti telah terjadi keberhasilan program, keberhasilan sasaran, serta pencapaian tujuan secara menyeluruh karena penambahan dana PADs secara signifikan telah berhasil mengurangi jumlah KK miskin di Kabupaten Kebumen tahun 2009-2011. Oleh karena itu, dapat diambil kesimpulan bahwa Pendapatan Asli Desa (PADs) efektif dalam mengurangi jumlah KK miskin di Kabupaten Kebumen tahun 2009-2011.

\section{IMPLIKASI PENELITIAN}

Berdasarkan kesimpulan diatas, maka implikasi penelitian yang dapat peneliti berikan adalah sebagai berikut

1. Variabel PNPM Mandiri Perdesaan-Simpan Pinjam Perempuan belum efektif dalam pengentasan kemiskinan di Kabupaten Kebumen pada tahun 2009-2011. Hal ini karena dalam pelaksanaan PNPM Mandiri Perdesaan - SPP di lapangan tidak sedikit adanya berbagai kendala dan penyimpangan, diantaranya penyimpangan dana berasal dari pengurus UPK, ketua kelompok dan aparatur desa dan elemen lainnya dengan modus operandi penyimpangan dana, seperti membuat kelompok fiktif, rekayasa laporan keuangan, angsuran dibawa pengurus kelompok, tidak disetor ke UPK dan rekayasa pinjaman. Di samping itu, modus lainnya, yakni bekerjasama dengan bank setempat untuk merekayasa rekening perguliran dan memanfaatkan dana kas (cash on hand). Menyikapi kondisi tersebut, peneliti memberikan beberapa saran untuk mencegah timbulnya masalah-masalah di atas, diantaranya dengan menerbitkan kebijakan yaitu :a). untuk mencegah kelompok fiktif, melalui FK-FT wajib ikut kegiatan verifikasi perguliran, FK-FT wajib hadir dalam realisasi penyaluran dana pinjaman perguliran, pembayaran angsuran langsung dari pengurus kelompok ke pengurus UPK (tidak diperkenankan titip kepada perangkat desa atau pelaku lain), dan FK-FT melakukan konfirmasi ke kelompok/anggota jika terjadi kelambatan angsuran; b). untuk 
pencegahan rekayasa rekening oleh pengurus UPK, dengan cara seluruh specimen rekening bank yang dikelola UPK (tidak hanya rekening BLM), wajib menyertakan tandatangan fasilitator, FK-FT juga Faskab wajib minta print out rekening ke Bank secara periodik, FK-FT melakukan pencocokan (rekonsiliasi) rekening dengan pembukuan UPK; c). UPK wajib membuat dan menyerahkan laporan keuangan kepada Satker Kabupaten (PMD), tidak hanya ke Faskab dan Badan Kerjasama Antar Desa; d). Penertiban panduan standar pembukuan UPK dan panduan tutup buku UPK. Di luar itu semua, di lapangan pun pelaksanaan PNPM-Mandiri Perdesaan-Simpan Pinjam Perempuan mengalami tantangan dan hambatan dalam penanganan masalah, yaitu : masyarakat merasa dana perguliran (aset UPK) adalah dana hibah, tidak merasa memiliki, lemahnya sistem data karena kurang didukung data yang memadai (hilang), tidak ada alokasi khusus untuk biaya penanganan masalah dan keterbatasan anggaran yang dimiliki oleh pihak penegak hukum dalam pemrosesan masalah PNPM Mandiri Perdesaan Simpan Pinjam Perempuan. Meskipun demikian, diakui atau tidak, pelaksanaan PNPM-MP selama ini banyak dirasakan manfaatnya oleh masyarakat, utamanya di pedesaan, karena PNPM Mandiri Perdesaan sudah berjalan baik (efisien), namun efektifitas pemanfaatan Bantuan Langsung Masyarakat perlu ditingkatkan, antara lain PNPM Mandiri Perdesaan perlu lebih fokus dalam menjangkau akses kelompok masyarakat miskin yang belum tersentuh oleh program (baik dalam pembangunan infrastruktur maupun SPP), meningkatkan bantuan dana bergulir agar dapat lebih lancar tersalurkan, tidak berhenti di UPK sehingga bisa dimanfaatkan oleh kelompok masyarakat lebih banyak lagi, serta peningkatan pemberdayaan ekonomi pada kelompok masyarakat yang terbukti bagus kinerja dan track record-nya (melalui kemitraan/jejaring sosial ekonomi).

2. Pelaksanaan PNPM Mandiri Perdesaan-NonSPP di Kabupaten Kebumen tahun 2009-2011 belum efektif untuk mengentaskan kemiskinan, karena meskipun dengan adanya program PNPM Perdesaan - NonSPP (misalnya berupa pembangunan infrastruktur fisik) telah berhasil mengurangi jumlah KK miskin, tetapi dalam jumlah yang tidak signifikan. Hal ini karena dalam jangka pendek program ini memang akan menciptakan lapangan pekerjaan bagi masyarakat miskin, tetapi dalam jangka panjang, ketika program PNPM Mandiri Perdesaan tersebut selesai, maka ada kemungkinan masyarakat miskin tersebut akan kembali menjadi pengangguran dan kembali lagi statusnya sebagai masyarakat miskin. Pelaksanaan PNPM Mandiri Perdesaan-NonSPP di 
Kabupaten Kebumen tahun 2009-2011 belum efektif untuk mengentaskan kemiskinan, karena yang merasakan manfaat lebih besar dari adanya kegiatan ini justru adalah pengusaha bahan bangunan yang bukan merupakan penduduk miskin. Penduduk miskin dalam kegiatan Pelaksanaan PNPM Mandiri Perdesaan-NonSPP hanya bertindak sebagai pekerja bayaran, yang segera akan kehilangan pekerjaan dan pendapatannya begitu kegiatan PNPM Mandiri PerdesaanNonSPP ini selesai. Akan tetapi, menurut peneliti, bukan berarti bahwa program ini gagal, hanya memang dampaknya baru akan dirasakan dalam jangka panjang. Untuk jangka pendek, perlu ditanamkan kepada seluruh masyarakat desa terutama penduduk miskin, bahwa pembangunan sarana prasarana yang dibiayai oleh PNPM Mandiri Perdesaan-NonSPP bertujuan untuk sarana peningkatan kegiatan ekonomi dan juga peningkatan kualitas SDM sehingga dihimbau kepada seluruh masyarakat untuk memanfaatkan dan melestarikan secara maksimal keberadaan sarana dan prasarana yang dibangun dengan dana PNPM Mandiri Perdesaan-NonSPP tersebut, sehingga tidak menjadi aset yang terbangun dengan sia-sia dan tidak berkontribusi terhadap peningkatan kesejahteraan masyarakat desa tersebut. Disini diperlukan peran serta dari para Fasilitator Kabupaten, Fasilitator Kecamatan, Fasilitator Desa dan semua pihak yang terkait untuk membangun kesadaran masyarakat desa.

3. Alokasi Dana Desa berpengaruh secara negatif dan signifikan terhadap jumlah KK miskin di tiap desa di Kabupaten Kebumen tahun 2009-2011. Hal ini sejalan dengan salah satu tujuan ADD yaitu untuk menanggulangi dampak kemiskinan, meningkatkan pemerataan pendapatan, kesempatan bekerja dan kesempatan berusaha bagi masyarakat, mengurangi kesenjangan masyarakat desa dengan mengembangkan kegiatan sosial dan ekonomi masyarakat, meningkatkan pembangunan infrastruktur pedesaan serta untuk meningkatkan pendapatan desa dan masyarakat desa. Oleh karena itu, untuk kedepannya, diharapkan jumlah alokasi dana ADD untuk program pemberdayaan dan pengentasan kemiskinan bisa diperbanyak jumlahnya.

4. Pendapatan Asli Desa berpengaruh secara negatif dan signifikan terhadap jumlah KK miskin per desa di Kabupaten Kebumen tahun 2009-2011. Hal ini berarti, ketika jumlah PADs suatu desa bertambah besar, maka jumlah KK miskin akan berkurang. Dari hasil penelitian tersebut, terlihat bagaimana peran penting PADs dalam meningkatkan kesejahteraan masyarakat desa tersebut. Oleh karena itu, pemerintah desa perlu terus menggali potensi yang dilimiliki oleh desa tersebut, supaya jumlah PADs meningkat. 
Diantara upaya yang bisa dilakukan adalah dengan: a). menginventarisir kekayaan desa, potensi dan pengembangannya yang meliputi tanah, barang dan kekayaan lainnya; b). melakukan kegiatan pelepasan, pengembangan, tukar menukar, alih fungsi dan pengamanan kekayaan desa; c). membangun pasar/kios, pemandian umum, pembangunan obyek rekreasi, pendirian tempat pelelangan ikan, pemanfaatan bangunan desa, pemanfaatan lapangan desa, menyewakan tanah kas desa atau usaha lain yang sah; d). meningkatkan penggalian PADs yang berasal dari swadaya, partisipasi, gotong-royong serta peningkatan jenis-jenis pungutan desa (selama tidak memberatkan masyarakat desa), yang pada akhirnya akan dapat meningkatkan Pendapatan Asli Desa (PADs).

5. Jika dianalisis secara simultan, variabel PNPM Mandiri Perdesaan-SPP, PNPM Mandiri Perdesaan-NonSPP, Alokasi Dana Desa dan Pendapatan Asli Desa secara bersama-sama berpengaruh secara signifikan terhadap jumlah KK miskin di Kabupaten Kebumen tahun 2009-2011. Hal ini menunjukkan bahwa variabelvariabel tersebut memang diperlukan untuk mengentaskan kemiskinan di pedesaan. Yang perlu terus dilakukan adalah mengoptimalkan fungsi dan manfaat dari dana-dana tersebut supaya lebih tepat sasaran, mendorong partisipasi seluruh masyarakat terutama masyarakat miskin dalam pengelolaan danadana tersebut serta peningkatan kualitas dan peran dari para fasilitator PNPM Mandiri Perdesaan serta instansi terkait lainnya, sehingga terjadi peningkatan kualitas dan kuantitas fasilitasi yang diberikan kepada masyarakat yang pada akhirnya akan meningkatkan pula efektifitas program PNPM Mandiri Perdesaan, ADD dan PADs dalam pengentasan kemiskinan di Kabupaten Kebumen untuk waktu yang akan datang.

6. Dalam penelitian ini, efektivitas hanya diukur dengan menggunakan 3 dari 5 indikator efektivitas yaitu keberhasilan program, keberhasilan sasaran dan pencapaian tujuan menyeluruh. Bagi peneliti lain yang tertarik untuk meneliti tentang efektivitas program pengentasan kemiskinan diharapkan dapat melakukan penelitian dengan menggunakan tambahan 2 indikator efektivitas yang lain yaitu kepuasan terhadap program dan tingkat input dan output sehingga diharapkan dapat memperoleh hasil penelitian yang lebih baik.

7. Diperlukan riset lain untuk menentukan bagaimana program dapat meningkatkan dampak terbesar melalui diversifikasi pendekatan pada implementasi proyek dalam konteks yang berbeda, karena untuk saat ini program menggunakan standar dimana satu-satunya variabel adalah jumlah dana hibah yang disesuaikan dengan jumlah penduduk dan status kemiskinan. 


\section{DAFTAR PUSTAKA}

Asian Development Bank. Poverty Assessment. http:/www.adb.org/ Documents/ Reports/Poverty-Assessment-INO/default.asp. Diakses tanggal 29 Oktober 2011

Asian Development Bank. 2006. Country Poverty Analysis for Indonesia. Diakses tanggal 29 Oktober 2011

Badan Pusat Statistik. Data Strategis BPS 2010. www.bps.go.id. Diakses tanggal 23 September 2010

Badan Perencanaan Pembangunan Nasional.http://simpadupnpm.bappenas.go.id. Diakses tanggal 12 Januari 2011

Baltagi, Badi H. 2005. Econometric Analysis of Panel Data. Third Edition. John Wiley \& Sons Ltd. England.

Fadly, Ferdy. Tutorial E-Views. http://ferdifadly.blogspot.com/2012/06/tutorial-e-viewspengujian-signifikansi.html Diakses tanggal 21 Desember 2012

Gustina, Indah. 2008. Implementasi ProgramPenanggulangan Kemiskinan di Perkotaan (P2KP) di Kecamatan Medan Maimun. Tesis. Sekolah Pascasarjana Universitas Sumatera Utara, Medan

Gordon, David. 2005. Indicators of Poverty and Hunger. University of Bristol. http://www.un.org/esa/socdev/unyin/documents/ydiDavidGordon_poverty.pdf.

Retrieved 2011-05-27. Diakses tanggal 11 Juli 2011

Grameen Bank. "Grameen Bank at A Glance". http://www.grameeninfo.org/index.php?option=com_content\&task=view\&id. Diakses tanggal 8 Juli 2011

Gujarati, Damodar N. 1995. Basics Econometrics. Third Edition. McGraw-Hill International Edition

Huraerah, Abu. 2006. Strategi Penanggulangan Kemiskinan. (on-line). Pikiran Rakyat, 02 Januari 2006. Diakses tanggal 12 Juni 2010

Haris, Ivan. 2010. Efektivitas Pelaksanaan Program Nasional Pemberdayaan Masyarakat Mandiri Perdesaan (PNPM-MP) Di Desa Pulo Dogom Kecamatan Kualuh Hulu Kabupaten Labuhan Batu Utara. Skripsi. Fakultas Ilmu Sosial dan Ilmu Politik Universitas Sumatera Utara, Medan (Tidak Dipublikasikan)

Haughton, Jonathan and Shahidur R. Khandker. 2009. Poverty + Inequality. The World Bank. http://www.worldbank.org/. Diakses tanggal 21 Februari 2011

Hermanto Siregar dan Dwi Wahyuniarti. 2006. Dampak Pertumbuhan Ekonomi Terhadap Penurunan Jumlah Penduduk Miskin. (on-line). Diakses tanggal 19 Februari 2011

Irfan Agustian Iswandaru. 2005. Implementasi Program Penanggulangan Kemiskinan di Perkotaan (P2KP) di Kelurahan Cepu, Kecamatan Cepu, Kabupaten Blora. Tesis. Magister Ilmu Administrasi Program Pascasarjana Universitas Diponegoro, Semarang

Indonesia Expanding Horizons. Mengurangi Kemiskinan. (online).siteresources.worldbank.org. Diakses tanggal 21 Juli 2010

Konsultasi Publik Raperda Penanggulangan Kemiskinan di Kabupaten Kebumen. Dilaksanakan tanggal 10 Pebruari 2011 di Hotel Candisari, Karanganyar Kebumen

Kementerian Koordinator Kesejahteraan Rakyat. www.menkokesra.go.id. Diakses tanggal 23 Januari 2011

Lister, Ruth. 2004. Poverty. Polity Press, Cambridge. Diakses tanggal 24 Agustus 2011

Lembaran Daerah Kabupaten Kebumen Nomor 3 Tahun 2007 Tentang Sumber Pendapatan Desa 
Masayanto, Ade. 2010. Target Penurunan Kemiskinan Masuk APBN. (on-line). www.kompas.com. Diakses tanggal 23 Februari 2011

Narayan, Deepa. 2002. Empowerment and Poverty Reduction : A Sourcebook. The World Bank, Washington DC. Diakses pada tanggal 11 Juli 2011

Nur Hadi. 2008. Kontradiksi BLT dan P2KP. http://www.p2kp.org/ forumdetil.asp. Diakses tanggal 22 Maret 2011

Pemerintah Kabupaten Kebumen. 2010. Rakor Evaluasi dan Sinkronisasi PNPM Mandiri Tahun 2010 Pemerintah Kabupaten Kebumen

Pemerintah Provinsi Jawa Tengah. www.jatengprov.go.id. Diakses tanggal 23 Februari 2011

Pemerintah Kabupaten Kebumen. www.kebumenkab.go.id. Diakses tanggal 23 Februari 2011

Pemerintah Kabupaten Gresik. www.gresik.go.id. Diakses tanggal 29 April 2011

Pemerintah Kabupaten Toba Samosir. Indikator Kemiskinan di Rumah Tangga.http: bersamatoba.com/ tobasa/berita/. Diakses tanggal 04 Oktober 2012

Peraturan Menteri Tenaga Kerja dan Transmigrasi Republik Indonesia Nomor: PER17/MEN/VIII/2005 Tentang Komponen dan Pelaksanaan Tahapan Pencapaian Kebutuhan Hidup Layak naker.tarakankota. go.id/ produkhukum/permen17- 2005.pdf. Diakses tanggal 7 Desember 2011

Peraturan Bupati Kebumen Nomor 44 Tahun 2009 tentang Alokasi Dana Desa di Kabupaten Kebumen Tahun Anggaran 2009

Peraturan Bupati Kebumen Nomor 85 Tahun 2010 tentang Alokasi Dana Desa di Kabupaten Kebumen Tahun Anggaran 2010

Peraturan Bupati Kebumen Nomor 38 Tahun 2011 tentang Alokasi Dana Desa di Kabupaten Kebumen Tahun Anggaran 2011

Program Nasional Pemberdayaan Masyarakat Mandiri Perdesaan. www.pnpm-perdesaan.or.id. Diakses tanggal 15 Maret 2010

Program Nasional Pemberdayaan Masyarakat Mandiri. www.pnpm-mandiri.org. Diakses tanggal 15 Maret 2010

Rumbewas, Spener. 2005. Poverty In Three Villages In Papua. Tesis. Doctor of Philosophy in Development Studies Massey University, Selandia Baru

Sagala, Otto Dwana. 2009. Evaluasi Program Nasional Pemberdayaan Mandiri Perdesaan Terhadap Pengembangan Sosio-Ekonomi dan Kesejahteraan Masyarakat di Kecamatan Balige Kabupaten Toba Samosir. Tesis. Sekolah Pascasarjana Universitas Sumatera Utara, Medan

Santoso, Lukman Adi. 2011. Pengaruh PNPM dan Alokasi Belanja Daerah Untuk Pendidikan, Kesehatan, dan Pekerjaan Umum Terhadap Penanggulangan Kemiskinan (Studi Kasus Kabupaten/Kota di Provinsi Jawa Timur Tahun 2007-2009). Tesis. Program Magister Perencanaan dan Kebijakan Publik Universitas Indonesia, Jakarta

Shah, Anup. 2011. Causes of Poverty. http://www.globalissues.org/issue/2/ causes-of-poverty. Diakses tanggal 7 Juli 2011

Siagian, James Erik. 2007. Analisis Dampak Pemberdayaan Masyarakat Melalui Program Pengembangan Kecamatan (PPK) Terhadap Pengentasan Kemiskinan di Kabupaten Deli Serdang (Studi Kasus di Kecamatan STM Hulu dan Kecamatan Pantai Labu). Tesis. Sekolah Pascasarjana Universitas Sumatera Utara, Medan

Simanjuntak, Wira Gusni. 2010. Analisis Alokasi Dana Desa (ADD) Serdang Bedagai Terhadap Pengembangan Desa di Kecamatan Sei Rampah. Tesis. Sekolah Pascasarjana Universitas Sumatera Utara, Medan 
Sutiyono. 2009. Efektivitas Pengelolaan Keuangan Desa (Studi Kasus Desa Seling Kecamatan Karangsambung Kabupaten Kebumen Tahun 2007-2008). Skripsi. Universitas Diponegoro

Sukesi. 2007. Efektivitas Program Alokasi Dana Desa (ADD) Terhadap Perekonomian Desa di Kabupaten Pacitan. Universitas Dr. Soetomo. Surabaya

Sugiyono. 2010. Statistika Untuk Penelitian. Jakarta : Alfabeta

Suliyanto. 2011. Ekonometrika Terapan : Teori \& Aplikasi Dengan SPSS. Penerbit Andi : Yogyakarta

Sekretariat Presiden Republik Indonesia. www.presidenri.go.id. Diakses tanggal 29 April 2011

The World Bank. 2001. World Development Report 2000/2001 : Causes of Poverty and A Framework For Action. (on-line). siteresources.worlbank.org. Diakses tanggal 15 Maret 2011

The World Bank. 2008. World Development Indicators. (on-line). siteresources.worlbank.org. Diakses tanggal 15 Maret 2011

The World Bank. www. data.worldbank.org. Diakses tanggal 29 Oktober 2011

The Australian Collaboration. Poverty and Its Causes. www.australian collaboration.com.au.Diakses tanggal 11 Juli 2011.

Tim Nasional Percepatan Penanggulangan Kemiskinan. www.tnp2k.wapresri. go.id. Diakses tanggal 23 Januari 2011

Todaro, Michael P. dan Stephen C. Smith. 2006. Pembangunan Ekonomi. Edisi Kesembilan. Jakarta : Penerbit Erlangga

Torres-Reyna, Oscar. Panel Data Analysis. Fixed \& Random Effects. Princeton University. http: //dss.princeton.edu/training/. Diakses tanggal 6 Maret 2013

Unando, Cindy Fristari. 2010. Efektivitas PNPM Mandiri Perdesaan Dalam Menanggulangi Kemiskinan (Studi Kasus:Program Simpan Pinjam Perempuan Pada PNPM Mandiri Perdesaan Di Kecamatan Tilatang Kamang, Kabupaten Agam). Skripsi. Fakultas Ilmu Sosial dan Ilmu Politik Universitas Andalas, Padang (Tidak Dipublikasikan)

United Nations Development Programme. Human Development Index. http://www.undp.org.bz/human-development/the-human-development-index-hdi.

Diakses tanggal 11 Juli 2011

United Nations Development Programme. www.undp.org. http://hdr.undp. org/en/ statistics/hdi/. Diakses tanggal 10 Desember 2011

Winarno, Wing Wahyu. 2011. Analisis Ekonometrika dan Statistika Dengan Eviews. Edisi 3. Yogyakarta : UPP STIM YKPN

www.britannica.com.http:/www.britannica.com/EBchecked/topic/473136/poverty 